\title{
Analysis of the polydispersity of soil-like bodies in glacier environments by the laser light scattering (diffraction) method
}

\author{
Evgeny Abakumov ${ }^{1}$, Timur Nizamutdinov ${ }^{1}$, and \\ Vyacheslav Polyakov ${ }^{1,2}$
}

1Department of Applied Ecology, Faculty of Biology, Saint Petersburg State University, 16 liniya V. O., 29, Saint Petersburg, 199178, Russian Federation

${ }^{2}$ Arctic and Antarctic Research Institute, ul. Beringa, 38, Saint Petersburg, 199397, Russian Federation

Address correspondence and requests for materials to Evgeny Abakumov, e_abakumov@mail.ru

Citation: Abakumov, E., Nizamutdinov, T. and Polyakov, V. 2021. Analysis of the polydispersity of soil-like bodies in glacier environments by the laser light scattering (diffraction) method. Bio. Comm. 66(3): 198-209. https://doi.org/10.21638/ spbu03.2021.302

Authors' information: Evgeny Abakumov, Dr. of Sci. in Soil Sciences, Professor, orcid.org/0000-0002-5248-9018; Timur Nizamutdinov, PhD Student, Research Engineer, orcid.org/0000-0003-2600-5494; Viacheslav Polyakov, PhD Student, Research Engineer, orcid.org/0000-0001-6171-3221

Manuscript Editor: Pavel Skutschas, Department of Vertebrate Zoology, Faculty of Biology, Saint Petersburg State University, Saint Petersburg, Russia

Received: January 13, 2021;

Revised: April 6, 2021;

Accepted: April 19, 2021.

Copyright: @ 2021 Abakumov et al. This is an open-access article distributed under the terms of the License Agreement with Saint Petersburg State University, which permits to the authors unrestricted distribution, and self-archiving free of charge.

Funding: This work was supported by Russian Foundation for Basic Research project No 19-05-50107.

Ethics statement: This paper does not contain any studies involving human participants or animals performed by any of the authors.

Competing interests: The authors have declared that no competing interests exist.

\section{Abstract}

This study presents the results of polydispersity analysis of soil-like bodies from two various polar regions using the laser light scattering method. The differences in the particle size distribution of cryoconite samples from the Anuchin Glacier (Antarctica) and the Mushketov Glacier (Arctic) are described. The samples obtained from the Mushketov Glacier are characterized by a finer particle size distribution than samples collected on the Anuchin Glacier. While comparing our results with previously published studies, it was found that the method of laser light scattering shows a lower content of small fractions $(<0.05 \mathrm{~mm})$ compared to the classical methods of sedimentation, since these methods are based on fundamentally different physical principles. The laser method used requires low amounts of samples (0.2-0.5 g), while the classical sedimentary method uses a higher gravimetric portion of cryoconite (5-10 g), which is critical for field sampling.

Keywords: soloids, cryoconites, Anuchin Glacier, Mushketov Glacier

\section{Introduction}

The surface of glaciers is never completely clean, and is highly susceptible to spatial and temporal fluctuations (Dumont, Durand, Arnaud and Six, 2012; Petrakov et al., 2019). Glaciers can accumulate on their surface dust particles of various origin, both natural and anthropogenic. The origin of sediments of aeolian or englaciar (Hildes, Clarke, Flowers and Marshall, 2004; Naoko Nagatsuka et al., 2016; Zawierucha et al., 2019) genesis can be revealed by analyzing their chemical, mineralogical and polydisperse composition, as well as by analyzing the meteorological and landscape features of subglacial areas (Glazovskaya, 1952; Ruth, Wagenbach, Steffensen and Bigler, 2003; Lee et al., 2008; Kutuzov et al., 2014).

The polydispersity or particle-size distribution of the solid phase of soils and soil-like bodies (in particular, cryoconites) influences many physical, chemical and biological properties of soils. Polydispersity has a decisive influence on the formation of water-air and thermal regimes of soils and their sorption capacity (Kachinsky, 1958; Kowalski and Andrianova, 1970; Gagarina, 2004; Shein, 2005, 2009; Shein and Madi, 2018).

In current studies, classical sedimentation methods (Kachinsky, 1958; EV. Shein, 2009) to determine polydispersity are increasingly used in conjunction with the more advanced method of laser light scattering (diffraction) (Gee and Or, 2002; Mukhametova, Abakumov and Rumin, 2013; Shein and Madi, 2018).

The use of the laser diffractometry method in the analysis of polydispersity of primitive mineral soils and soil-like bodies of the Arctic and Antarctic is of 

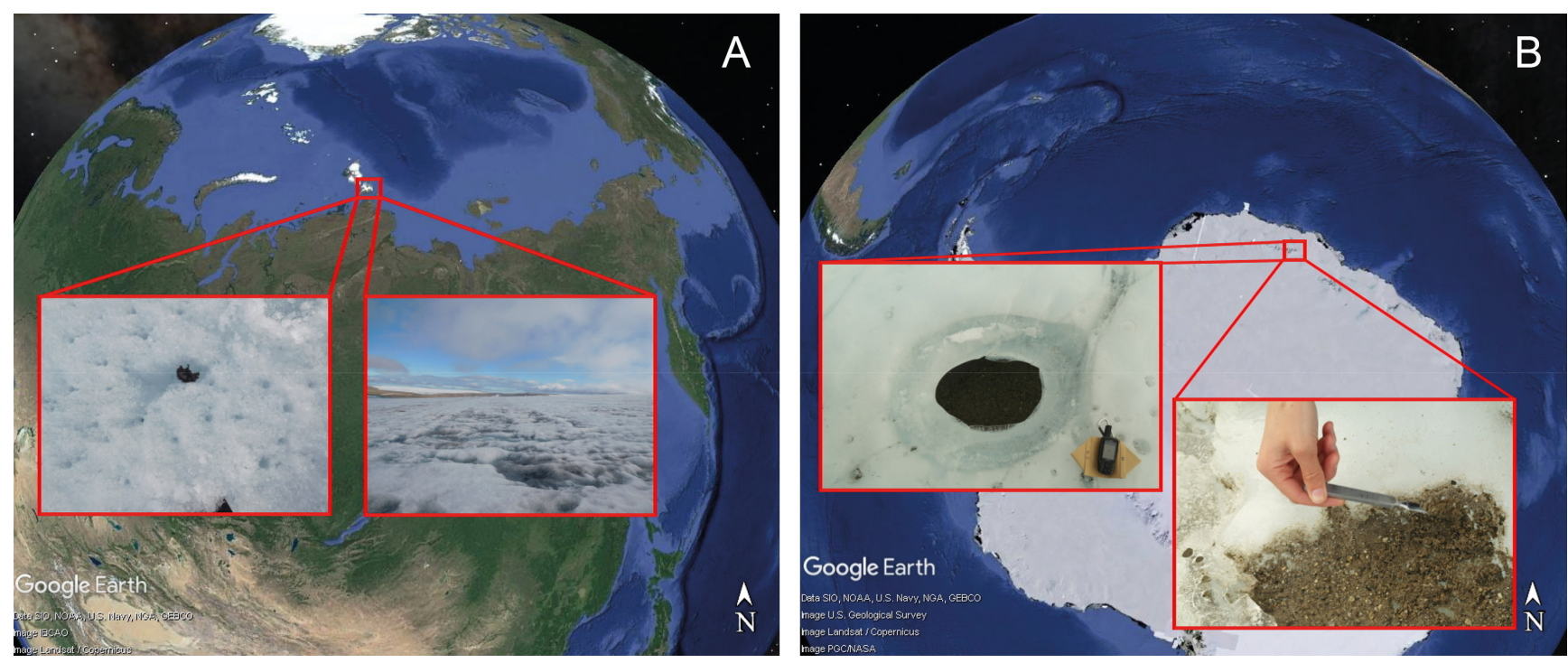

Fig. 1. Cryoconites in sampling area. A - Cryoconite material on Mushketova Glacier (Cape Baranova, Russian Arctic); B - Cryoconite hole founded in Untersee Oasis (Anuchin Glacier, Queen Maud Land, East Antarctida).

particular importance, since the classical sedimentological methods of analysis overestimate the data on silt and finely-dispersed dust content. Correct values of silt and clay content are crucial for understanding the processes of soil formation in polar and high-mountain regions and for understanding the level of absorption capacity of soils and soil-like bodies (Glazovskaya, 1958; Shein, 2005; Abakumov, Pomelov, Krylenkov and Vlasov, 2008; Abakumov, 2010).

On the surface of polar and high-mountain glaciers, ice shelves or sea ice you can frequently find dark-colored clusters of surface dust; these are called cryoconites (Mueller and Pollard, 2004; Nozomu Takeuchi and Li, 2008; Joseph Cook, Edwards, Takeuchi, and Irvine-Fynn, 2016). Cryoconites are sediments of predominantly aeolian genesis; material in cryoconites can also accumulate as a result of landslides of mineral and organic matter from valley walls, and supraglacial and englacial entrainment (MacDonell and Fitzsimons, 2008; Wientjes et al., 2011; Shishkov et al., 2016; Li et al., 2017).

In places of accumulation of dark-colored finegrained sand, cryoconites form on the glacier surface, which can absorb a much greater amount of solar radiation (Hodson et al., 2008; MacDonell and Fitzsimons, 2008; Cook, Edwards, Takeuchi and Irvine-Fynn, 2016; Abakumov, Gijanski, Chigray and Polyakov, 2020). As a result of the significant difference in albedo between the clear pure glacier surface and the dark-colored cryoconites, active thawing of the glacier body and formation of cryoconite holes (Fig. 1) begin under these dust accumulations (McIntyre, 1984; Wharton Jr, McKay, Simmons Jr and Parker, 1985; MacDonell and Fitzsimons, 2008).

Normally, cryoconite holes do not reach the size of $10 \mathrm{~cm}$ vertically and horizontally, but in some cases there are holes even up to 1 meter (Fountain et al., 2004; Mueller and Pollard, 2004; Gajda, 2008).

A cryoconite hole is a water-filled cylindrical depression of tube form with nearly vertical or D-shaped sides (McIntyre, 1984; Wharton Jr, McKay, Simmons Jr and Parker, 1985). Cryoconites consist not only of mineral components (85-95\%), but also of organic matter - they can contain the plant remnants of mosses, algae, bacteria and lichens (Takeuchi, Kohshima and Seko, 2001; Takeuchi, 2002; Cook, Edwards, Takeuchi and Irvine-Fynn, 2016).

The presence of organic matter is responsible for the dark color of cryoconites (Cook, Edwards, Takeuchi, and Irvine-Fynn, 2016). A microclimate is formed in cryoconite holes, which contributes to the growth of primary producers such as cyanobacteria and green algae, which subsequently enrich the cryoconite with biogenic materials (Langford, Hodson, Banwart and Bøggild, 2010; Nagatsuka, Takeuchi, Uetake and Shimada, 2014; Weisleitner et al., 2020). Many authors have noted the rich biodiversity of the microbiome developing in cryoconite holes. Cryoconite holes are a favorable environment for the development of cyanobacteria, Bacteroidetes, Actinobacteria, Proteobacteria and some other bacteria species (Cook et al., 2010; Langford, Hodson, Banwart and Bøggild, 2010; Cameron, Hodson and Osborn, 2012; Cook, Edwards, Takeuchi and Irvine-Fynn, 2016; Weisleitner et al., 2019; Weisleitner et al., 2020). The combination of all these factors makes the organomineral compounds of cryoconites a unique soil-forming structure that remains on the bedrock after the retreat and thawing of the glacier (Singh et al., 2013; Shishkov, Zazovskaya, Mergelov and Dolgikh, 2017; Abakumov, Gijanski, Chigray, and Polyakov, 2020). 


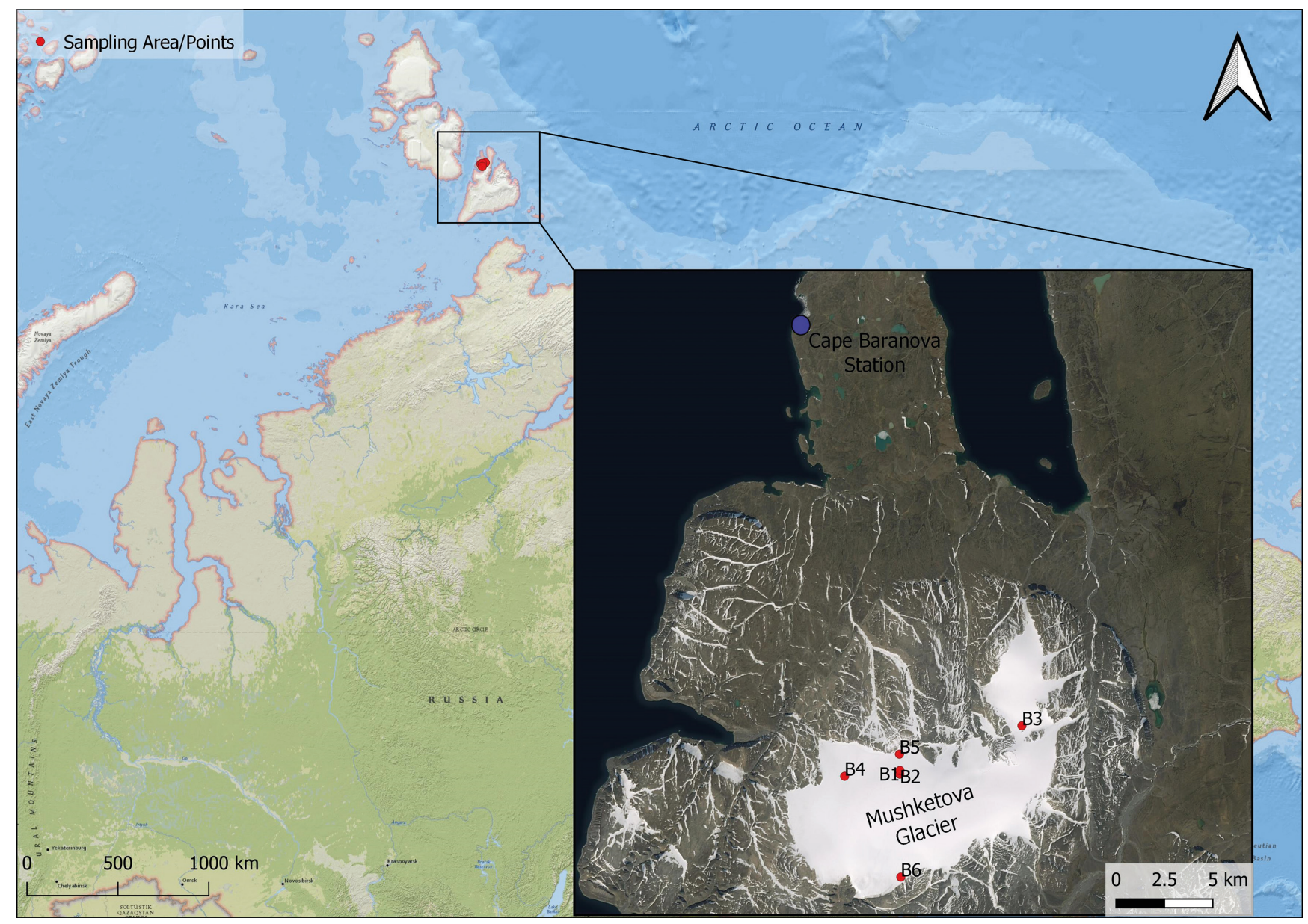

Fig. 2. Regional setting and sampling points at the Mushketov Glacier ("Topographic", February 19, 2012).

Cryoconites are of particular interest to study not only in terms of their unique pedogenic, bioaccumulating and organogenic properties. Cryoconite material includes dust from distant continental deserts or agricultural lands, particles from volcanic eruptions or industrial emissions and soot due to its aeolian origin. The analysis of the particle size distribution of soloids (Goryachkin, Mergelov and Targulian, 2019) allows us to establish their genesis in relation to the source of aeolian material (Bizzotto, Villa, Vaj, and Vighi, 2009; Tieber et al., 2009; Mauro et al., 2016). This makes cryoconites a geochemical indicator of transboundary anthropogenic impact on nival-glacial and periglacial areas.

According to other studies, cryoconites are able to accumulate radionuclides of anthropogenic origin (Tieber et al., 2009; Łokas et al., 2018; Usyagina, Ilyin, Meshcheryakov, and Valuyskaya, 2019; Baccolo et al., 2020), potentially toxic elements (Singh et al., 2013; Ferrario et al., 2017; Owens, Blake, and Millward, 2019), polycyclic aromatic hydrocarbons and other synthetic organic compounds (Li et al., 2017; Weiland-Bräuer, Fischer, Schramm, and Schmitz, 2017).
The aim of this work is to compare the polydisperse composition of soil-like bodies of polar regions. To achieve this goal, the following objectives were set: determine the polydisperse composition of cryoconite material using the method of laser diffraction; compare the results with previous studies; identify patterns between the grain-size distribution of soil-like bodies and features of glacial landscapes.

\section{Materials and methods}

Polar expeditions have resulted in cryoconite samples collected from the Mushketov Glacier (Bolshevik Island, Severnaya Zemlya Archipelago, $23 \mathrm{~km}$ south of the Cape Baranova Arctic Station) and the Anuchin Glacier (Lake Untersee, Queen Maud Land, East Antarctica, $90 \mathrm{~km}$ south of the Russian Antarctic station Novolazarevskaya).

Detailed maps of the study areas can be seen in Figures 2 and 3.

The Mushketov Glacier is a glacial dome with an area of about $89 \mathrm{~km}^{2}$ and an ice thickness of about 


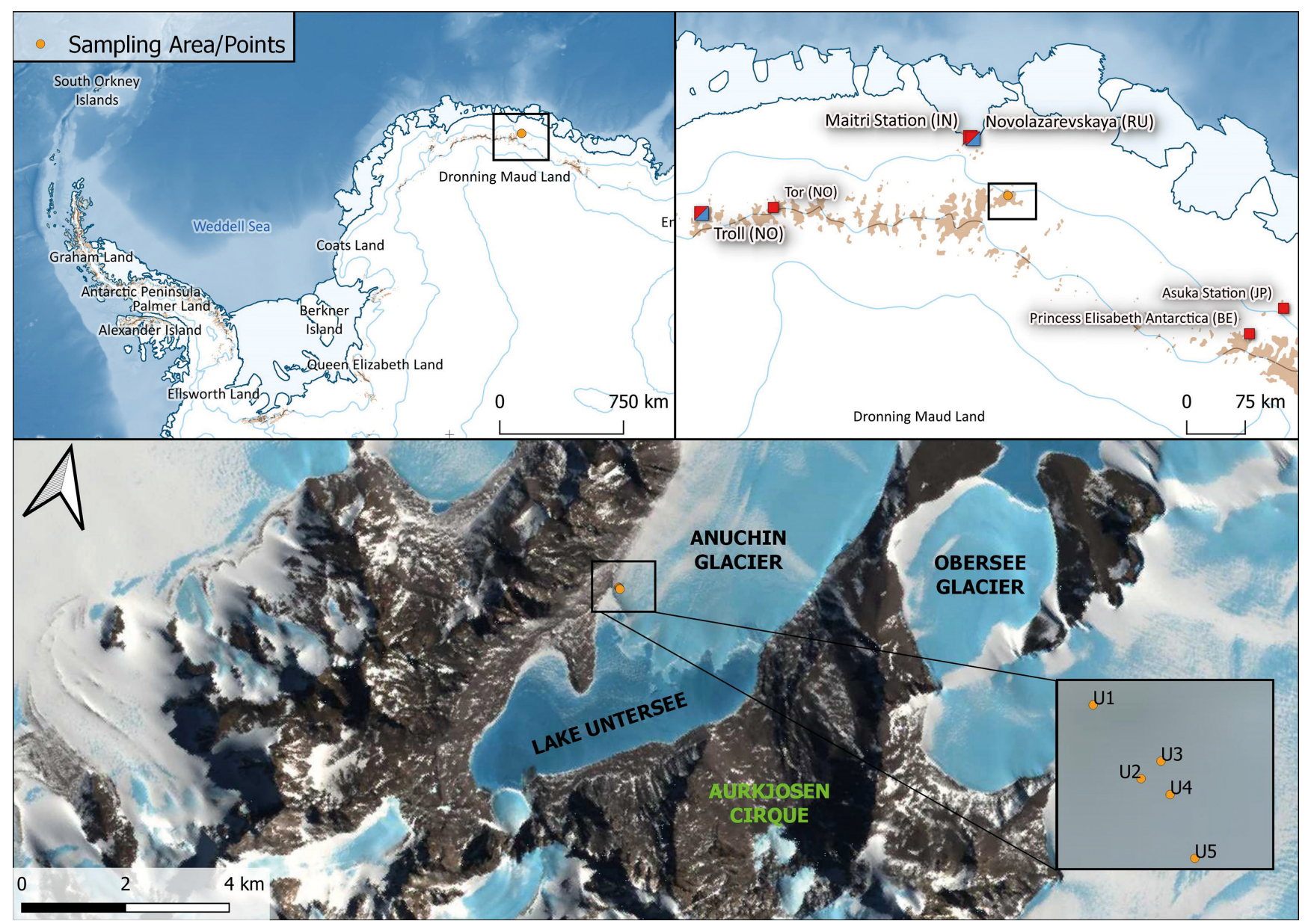

Fig. 3. Study area and sampling points at the Anuchin Glacier (Matsuoka, Skoglund, and Roth, 2018)

$160 \mathrm{~m}$, located on the surface of the upper denudation leveling (Bolshiyanov et al., 2016). The island is composed of the Upper Proterozoic terrigenous complex (sandstones, siltstones, granodiorites). Average annual air temperature is $-14^{\circ} \mathrm{C}$. The most commonly distributed plants are Saxifraga cernua, S. hyperborea and Stellaria edwardsii; mosses Polytrichastrum alpinum and Sanionia uncinata; and lichen Stereocaulon rivulorum (Bolshiyanov and Makeev, 1995; Matveyeva, 2006). The area is characterized by stable winds mainly from the southern direction with an average speed of $10-15 \mathrm{~m} / \mathrm{s}$ (Manousakas et al., 2020).

The Anuchin Glacier is part of the ice cap of Antarctica, the surface of the glacier has southern exposure, and the surface area of the glacier is $34 \mathrm{~km}^{2}$. The coverage of cryoconite holes on the Anuchin Glacier is $3.5 \%\left(1.2 \mathrm{~km}^{2}\right)$ on average, with highest density observed near the glacier-lake interface in the southwestern part of the glacier (Weisleitner et al., 2019). The glacial surface has a pronounced cell-polygonal character. Southerly winds prevail, with an average daily maximum of $15 \mathrm{~m} / \mathrm{s}$ (Levitan et al., 2011; Weisleitner et al., 2019). No regular vegetation was found close to the sampling points.

After collection, the samples were air dried and transported to the laboratory of the Department of Applied Ecology of SPBU for further analysis. Before the analysis, the field samples were put through a sieve with a diameter of $2 \mathrm{~mm}$, and weighed. The polydispersity of soil-like bodies was analyzed by the laser light scattering (diffraction) method according to the Russian method "GPM 1.2.1.0008.15 Determination of particle size distribution by laser light diffraction" with repeated measurements for each sample (GPM, 2016).

The method is based on the principle that particles of a given size diffract light at a certain angle that increases with decreasing particle size. This method allows detection of particles of the size from $0.1 \mu \mathrm{m}$ to $2000 \mu \mathrm{m}$ (Gee and Or, 2002; Domkin, 2011; Uspenskaya, Syroeshkin, Pleteneva and Dobrovolsky, 2016). The laser diffraction method is more effective for measuring sand and silt fractions compared to sedimentation methods for analyzing the particle-size distribution of soils (Shein, 2009; Shein and Madi, 2018). 
Samples were placed in $10 \mathrm{ml}$ of $4 \% \mathrm{Na}_{4} \mathrm{P}_{2} \mathrm{O}_{7}$ solution for peptization of colloids before analysis, followed by grinding.

The processed sample was separated on a sieve with a diameter of $0.25 \mathrm{~mm}$. Particles remaining on the sieve were washed into a bowl and dried to a constant weight at $105^{\circ} \mathrm{C}$, after which they were weighed on an analytical scale. The mass of the sample was found from the difference of masses, and the percentage of 1-0.25 mm fraction was calculated.

Fraction distribution in the range of $0.03-250 \mu \mathrm{m}$ was determined on a Shimadzu SALD-2201 (Japan) device. Blank measurement was carried out with distilled water. The refractive index of 3.0-0.2i was used to process the results. Measurement on the diffractometer was carried out in at least threefold repeats.

Statistical data processing and visualization of the results were performed using Statsoft Statistica v12.5, TriQuick, and QGIS 3.16.

\section{Results and discussions}

In some studies cryoconites classify as a specific type of soil - soloids or soil-like bodies (Targulian, Mergelov and Goryachkin, 2017; Goryachkin, Mergelov and Targulian, 2019). This assumption allows us to consider cryoconites as Lithic skeletal and mineral soils and to use all the fundamental principles of classical soil science to study them.

As previously mentioned, cryoconites can be geochemical indicators of transboundary anthropogenic impact on nival-glacial and periglacial areas. The particlesize distribution, specific surface area of soil colloids, and microaggregate composition play an important function in the sorption capacity of soils (EV Shein, 2005), including the accumulation of pollutants in soils and soloids. It is known that a significant part of trace elements is accumulated in the fine-graded $(<0.005 \mathrm{~mm})$ fraction due to the high absorption capacity of the clay fraction (Kowalski and Andrianova, 1970; Gagarina, 2004).

\section{Results of polydispersity analysis}

The results of the polydispersity analysis of cryoconites are shown in Table 1, with classification into fractional classes according to Kachinsky (1937). We can see that cryoconites from two different study areas have a different particle-size distribution.

Samples from the Anuchin Glacier (East Antarctica) are characterized by sandy composition. In all selected cryoconite samples, the content of sand fractions dominates. The minimum content of average sand was in sample U3 - 76.31\%; the maximum in U5 $97.12 \%$. The content of fine sand in the samples varies from $1.84 \%$ in U5 to $15.35 \%$ in U3. The percentage of finer fractions (medium and fine dust) in all samples is less than one percent, except for U3, which had $1.21 \%$ medium dust and $2.10 \%$ small silt. The percentage of large silt in all samples is $<5 \%$. The content of clay particles in all samples was $<1 \%$.

Cryoconites from the Mushketov Glacier (Russian Arctic) are more finely dispersed compared to samples from the Anuchin Glacier. In the particle-size distribution, there is a large fraction of fine sands and coarse dust. The small sand content varies from $42.95 \%$ in B2 to $54.05 \%$ in B6. The minimum content of large silt was found in sample B6 - 20.80\%; the maximum in the sample B3 - 49.19\%. The percentage of medium sand fraction was $<15 \%$. The maximum fraction of medium sand was found in samples B1, B3, and B6 at 11.71, 14.56, and $15.88 \%$, respectively. Medium and small silt

Table 1. Contents of particle size classes, \% ( $\pm 95 \%$ Confidence Interval) (Kachinsky 1937)

\begin{tabular}{|c|c|c|c|c|c|c|c|}
\hline & & $\begin{array}{l}\text { Medium sand } \\
(>0.25 \mathrm{~mm})\end{array}$ & $\begin{array}{c}\text { Fine sand } \\
(0.25-0.05 \mathrm{~mm})\end{array}$ & $\begin{array}{c}\text { Large silt } \\
(0.05-0.01 \mathrm{~mm})\end{array}$ & $\begin{array}{c}\text { Medium silt } \\
(0.01-0.005 \mathrm{~mm})\end{array}$ & $\begin{array}{c}\text { Fine silt } \\
(0.005-0.001 \mathrm{~mm})\end{array}$ & $\begin{array}{c}\text { Clay } \\
(<0.001 \mathrm{~mm})\end{array}$ \\
\hline \multirow{5}{*}{ 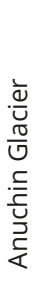 } & U1 & $88.94 \pm 0.11$ & $7.87 \pm 0.20$ & $2.29 \pm 0.10$ & $0.35 \pm 0.03$ & $0.44 \pm 0.05$ & $0.12 \pm 0.05$ \\
\hline & U2 & $85.17 \pm 0.28$ & $10.31 \pm 0.38$ & $2.91 \pm 0.33$ & $0.63 \pm 0.08$ & $0.87 \pm 0.15$ & $0.11 \pm 0.10$ \\
\hline & U3 & $76.31 \pm 0.21$ & $15.35 \pm 0.46$ & $4.46 \pm 0.61$ & $1.21 \pm 0.05$ & $2.10 \pm 0.08$ & $0.57 \pm 0.11$ \\
\hline & U4 & $94.52 \pm 0.07$ & $3.80 \pm 0.06$ & $1.15 \pm 0.04$ & $0.23 \pm 0.01$ & $0.25 \pm 0.01$ & $0.06 \pm 0.03$ \\
\hline & U5 & $97.12 \pm 0.03$ & $1.84 \pm 0.03$ & $0.70 \pm 0.02$ & $0.14 \pm 0.00$ & $0.17 \pm 0.01$ & $0.03 \pm 0.01$ \\
\hline \multirow{6}{*}{ 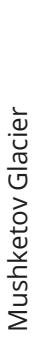 } & B1 & $11.71 \pm 1.62$ & $50.78 \pm 0.83$ & $25.62 \pm 1.07$ & $5.46 \pm 0.27$ & $5.30 \pm 0.31$ & $1.12 \pm 0.90$ \\
\hline & B2 & $2.46 \pm 0.84$ & $42.95 \pm 1.15$ & $39.49 \pm 1.23$ & $7.75 \pm 0.32$ & $5.92 \pm 0.29$ & $1.43 \pm 1.42$ \\
\hline & B3 & $14.56 \pm 2.90$ & $49.19 \pm 2.68$ & $24.20 \pm 0.66$ & $5.89 \pm 0.03$ & $5.80 \pm 0.32$ & $0.36 \pm 0.44$ \\
\hline & B4 & $5.04 \pm 1.07$ & $52.35 \pm 2.86$ & $29.99 \pm 1.51$ & $6.36 \pm 0.55$ & $5.66 \pm 0.67$ & $0.60 \pm 0.26$ \\
\hline & B5 & $2.77 \pm 0.37$ & $47.87 \pm 2.04$ & $34.00 \pm 1.23$ & $7.48 \pm 0.40$ & $6.77 \pm 0.54$ & $1.11 \pm 1.07$ \\
\hline & B6 & $15.88 \pm 1.65$ & $54.05 \pm 1.58$ & $20.80 \pm 0.19$ & $4.30 \pm 0.07$ & $4.43 \pm 0.20$ & $0.54 \pm 0.24$ \\
\hline
\end{tabular}




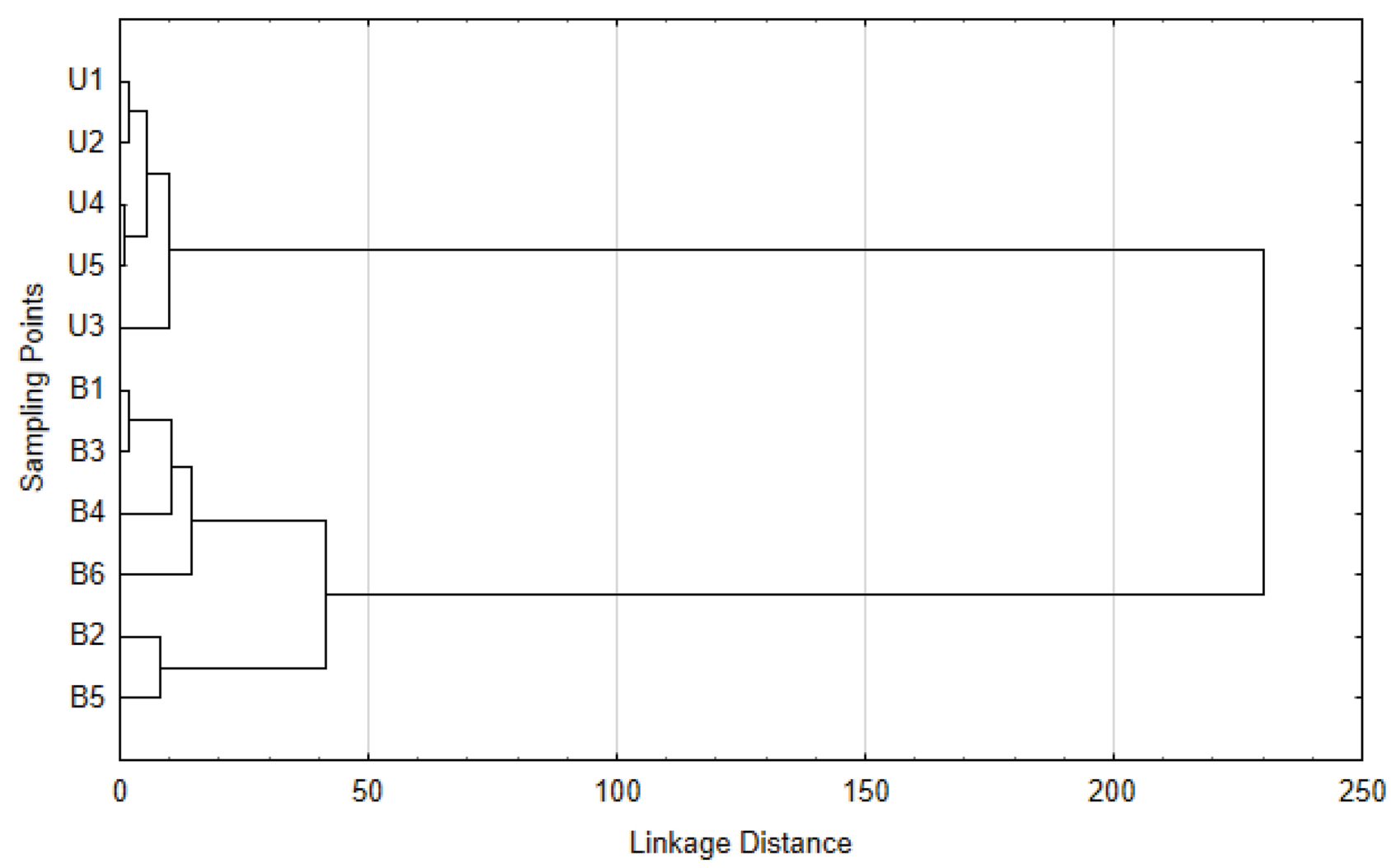

Fig. 4. Cluster Tree Diagram for 11 samples of cryoconites from cape Baranov (B1-6) and Untersee oasis (U1-5). For cluster analysis we used Ward's method with Euclidean distance metrics.

content in all samples was $<8 \%$. The percentage of the clay fraction ranges from $0.36 \%$ in $\mathrm{B} 3$ to $1.43 \%$ in $\mathrm{B} 2$.

Cluster analysis of the obtained data using the (Ward, 1963) method with the Euclidean metric statistically confirmed the difference in the particle-size distribution in the two study areas. As you can see in the diagram in Figure 4, the data were divided into two clusters. One cluster - points U1-U5, contains all samples obtained from the Anuchin Glacier (East Antarctica). The second cluster - points B1-B6, contains all samples obtained from the Mushketov Glacier (Russian Arctic).

To understand which textural classes the studied cryoconite samples relate to, a ternary plot of particle sizes (Figs. 5 and 6) was constructed for each study area. Classification of texture classes was performed according to the triangular diagram (Jahn et al., 2006). To construct the plots, the total percentages of sand, \% (medium sand + fine sand), silt, \% (large + medium + fine silt) and clay, $\%$ were pre-calculated.

As can be seen in the ternary plot (Fig. 3), the material from the cryoconite holes collected at the Anuchin glacier can be classified as sand. A more detailed consideration shows that the content of clay particles for all samples (except for U3) is $<1 \%$. The content of sand fraction varies from $91 \%$ in U3 to $99 \%$ in U5.
The samples collected from the Mushketov Glacier are very different from the material from the Anuchin Glacier. The cryoconite material from the Mushketov Glacier is finer. According to the textural class (Fig. 4), samples B1, B3, B4, and B6 belong to Sandy Loam; B2 and B5 - to Loam (WRB, 2015).

The highest variability is in the sand and silt fractions. The sand fraction varies from $45 \%$ in B2 to $70 \%$ in B6. The variability of the silt fraction ranged from 25 to $47 \%$ for samples B6 and B2, respectively.

\section{Discussions}

Cryoconites have an important role in the formation and regulation of the current climatic situation. The accumulation rate and quantity of cryoconite material on the surface of glaciers is directly related to their degradation (Wharton Jr, McKay, Simmons Jr and Parker, 1985; Podgorny and Grenfell, 1996; Fountain et al., 2004 ) and the intensity of aeolian processes (Glazovskaya, 1952). Since the accumulation of matter in cryoconite holes is mainly related to aeolian processes, it is important to understand the primary nature of the origin of the particles that accumulate on the glacier surface. Cryoconite material can play the role of a geo- 


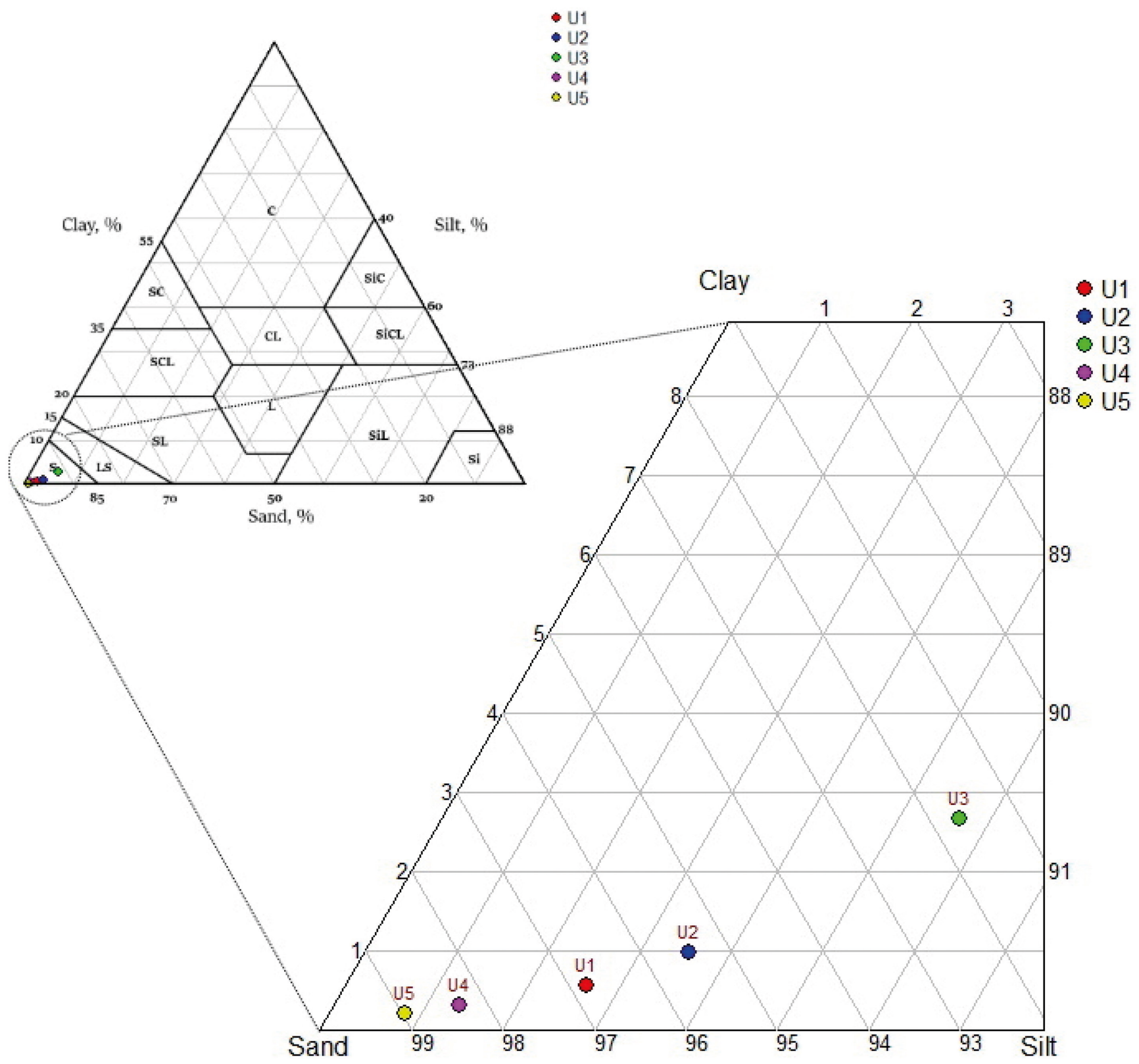

Fig. 5. Ternary plot of particle sizes for cryoconite samples from Anuchin Glacier (fractional content, \%).

chemical indicator of anthropogenic impact on glacial areas. By understanding the nature of the origin of the cryoconite material, it is possible to assess the degree of influence of the anthropogenic factor on the melting of glaciers. In this context, it is important to obtain reliable data on the particle-size distribution of sediments of aeolian genesis (Glazovskaya, 1952). The setting of traps on the glacier surfaces will assist to collect and sample migratory material of various origin (dust, fluvial grains). Since black carbon particles of anthropogenic origin (which are emitted by incomplete combustion of coal, wood, and fossil fuels (Goldberg, 1985; Masiello, 2004; Ramanathan and Carmichael, 2008; Baccolo et al., 2020) accumulate predominantly in clay particles (Glazovskaya, 1958; Ukalska-Jaruga, Smreczak and Klimkowicz-Pawlas, 2019), the quantitative evaluation of grain size distribution becomes quite important for glacier surface retreat rate.

As mentioned earlier, the use of classical sedimentation methods to estimate the particle-size distribution often overestimates the percentage of fine fractions in comparison with the results obtained by laser diffractometry (Abakumov, Pomelov, Krylenkov and Vlasov, 2008; Shein, 2009; Shein and Madi, 2018).

Some researchers have already studied the particle-size distribution of cryoconite and moraine aggregates around Lake Untersee and the Anuchin Glacier (Levitan et al., 2011; Weisleitner et al., 2019; Weisleitner 


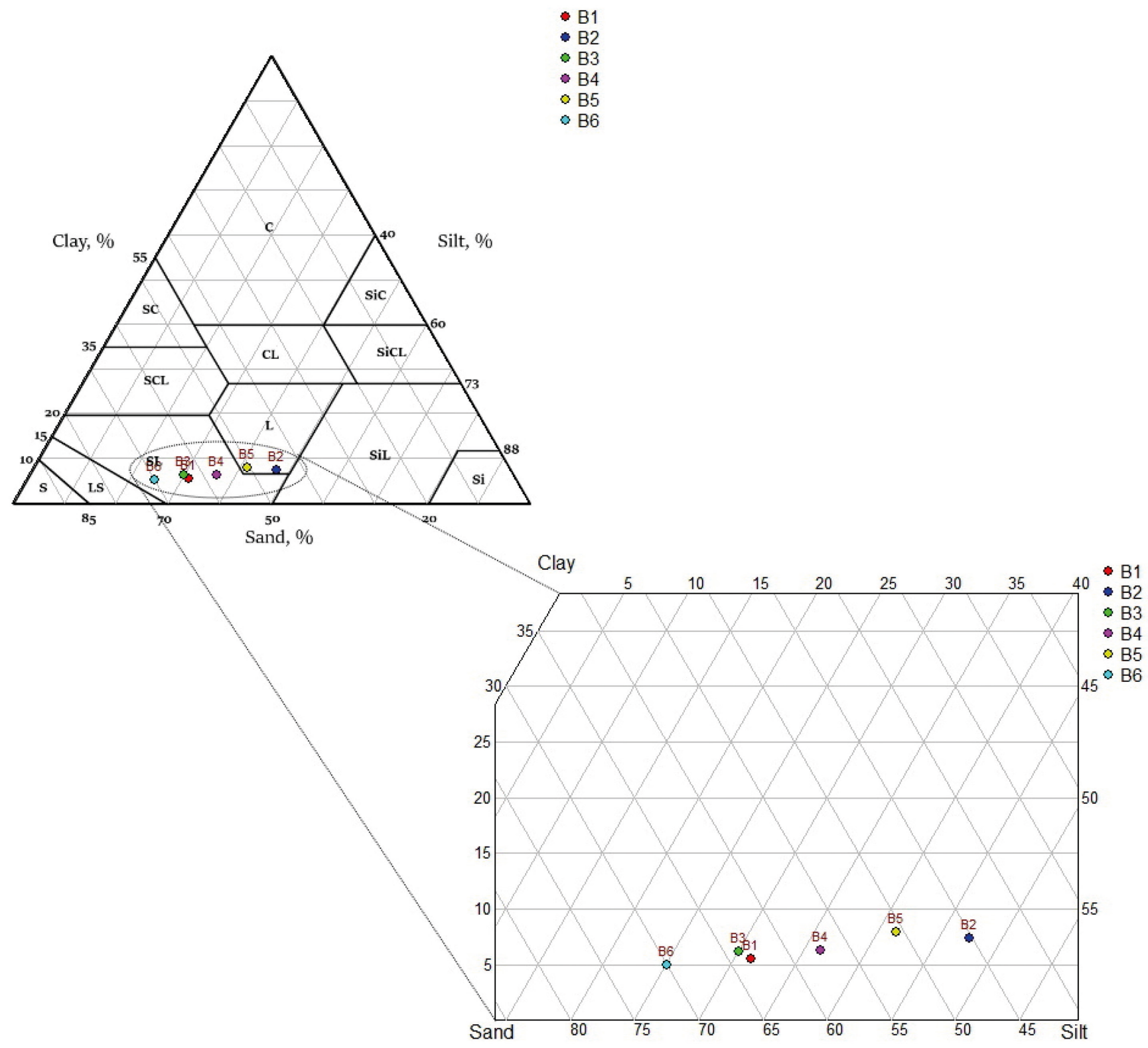

Fig. 6. Ternary plot of particle sizes for cryoconite samples from Mushketov Glacier (fractional content, \%).

et al., 2020). For the Mushketov Glacier area, it appears that we performed this analysis for the first time.

Weisleitner et al. (2020) used the wet sieving method. It should be noted that their study area is very close to our sampling sites. They investigated samples of material from cryoconite holes on the Anuchin Glacier in the Anuchin North of Ridge (ANR) and on the glacier along the medial moraine (AMH, AML). Levitan et al. (2011) researched the particle-size distribution of moraine deposits and "dirty ice" in the vicinity of Lake Untersee and the Anuchin Glacier using the classical sedimentation (water-mechanical) method. We made a comparison of our results with the results published earlier (Levitan et al., 2011; Weisleitner et al., 2020; Weisleitner et al., 2020); a comparative diagram can be seen in Figure 7.
The results obtained during our research differ significantly from the results of previously published investigations. The use of laser diffractometry showed a lower percentage of fine fractions $(<0.01 \mathrm{~mm})$. Mostly the percentage fraction $<0.01 \mathrm{~mm}$ is less than $2 \%$. The results of other studies significantly varied, up to $4.5 \%$ with the wet sieving method (Weisleitner et al., 2020) and up to $12.3 \%$ with the classical sedimentation method (Levitan et al., 2011).

\section{Conclusions}

The variations in the polydisperse composition of cryoconites can be associated with differences in the conditions of cryoconite hole formation and the in- 


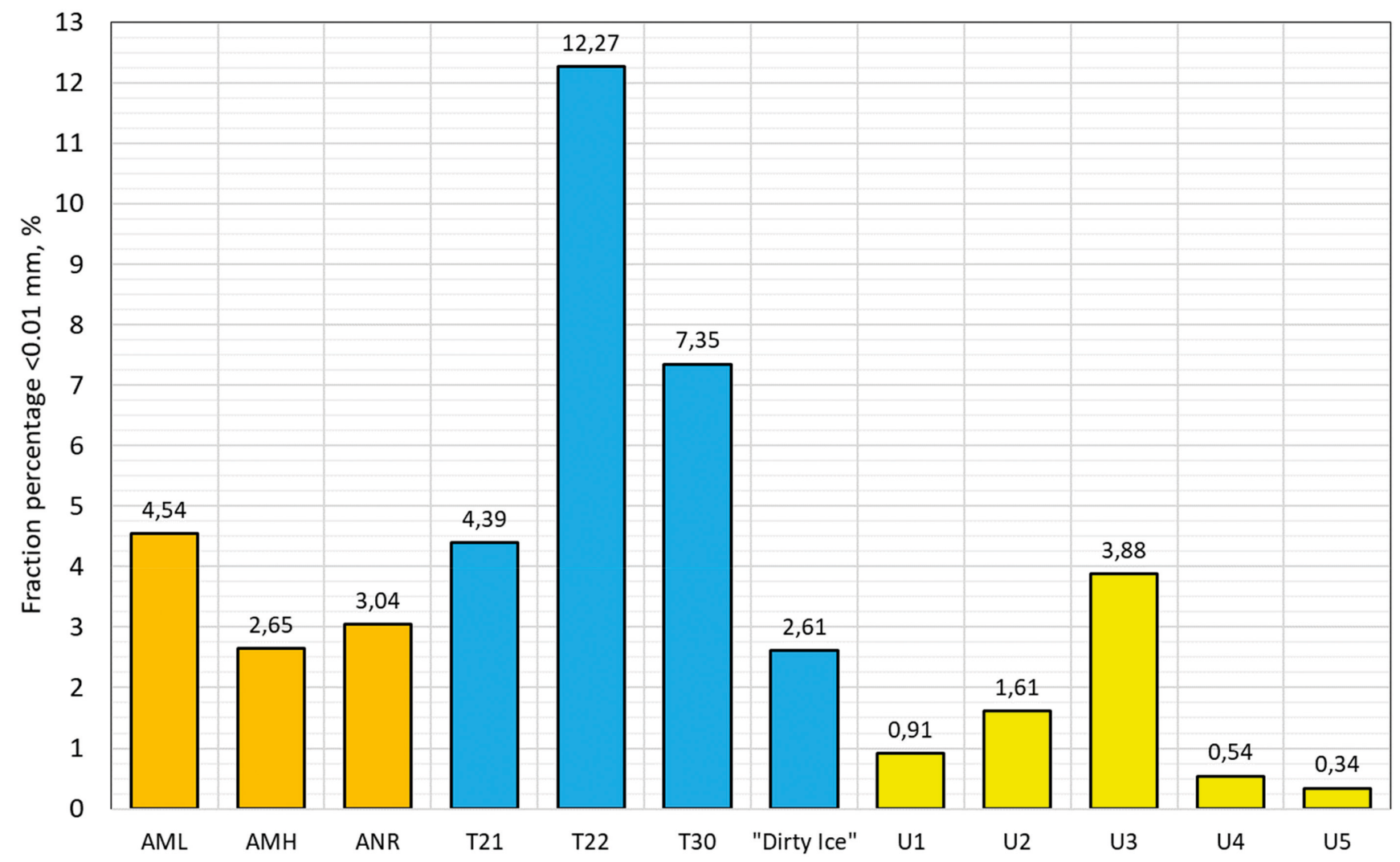

Fig. 7. Percentage of the fine fractions $<0.01 \mathrm{~mm}, \%$. T21, T22, T30, “Dirty Ice” (Levitan et al., 2011), WIP, AML, AMH, ANR (Weisleitner et al., 2019).

fluence of local landscapes on aeolian sedimentation processes. The Anuchin Glacier and Lake Untersee are surrounded by the Gruber Mountains, which may limit aeolian mass transfer processes. The cryoconite material in the cryoconite holes on the Anuchin Glacier is characterized by a dominance of heavy fractions (medium sand, $>0.25 \mathrm{~mm}$ ). Accumulation of material occurs mainly as a result of landslides from glacier valley walls.

The mass transfer of fine fractions is not limited. Cryoconite holes on the Mushketov Glacier may be much more active in accumulating material of aeolian or englacial genesis. Probably, the accumulation of particles on the glacier has been taking place for a long time. The specific location of Bolshevik Island makes it highly affected by the transport of particles as a result of the polar circulation of air masses. Wind currents, as a result of the polar circulation, can bring in fine particles both from the mainland and from the more northern islands of the Severnaya Zemlya archipelago. Silt and clay fractions can be transported from the mainland or neighboring islands and easily deposited on the glacier surface and accumulate in the cryoconite holes. Therefore, the polydisperse composition of cryoconite material from the Mushketov Glacier is dominated by small sand and silt fractions $(0.25-0.01 \mathrm{~mm})$.

\section{Acknowledgments}

We would like to express our gratitude to Dmitry Bolshiyanov for his help in the selection and delivery of cryoconites to St. Petersburg, as well as his help in interpreting the data regarding the genesis of cryoconites.

\section{References}

Abakumov, E. 2010. Particle size distribution of soils in West Antarctica. Eurasian Soil Science 43(3):297-304. https:// doi.org/10.1134/S1064229310030075

Abakumov, E. V., Pomelov, V. N., Krylenkov, V.A., and Vlasov, D. Y. 2008. Morphological organization of soils in Western Antarctica. Vestnik Sankt-Peterburgskogo Universiteta. Seriya 3: Biologiya (3):102-116. (In Russian)

Abakumov, E. V., Gijanski, M., Chigray, S. N., and Polyakov, V. I. 2020. The role of birds in the formation of organo-mineral cryoconites on Subantarctic glaciers. The Russian Journal of Ornithology 29(1957). (In Russian)

Baccolo, G., Łokas, E., Gaca, P., Massabò, D., Ambrosini, R., Azzoni, R. S., Clason, C., Di Mauro, B., Franzetti, A., Nastasi, M., Prata, M., Prati, P., Previtali, E., Delmonte, B., and Maggi, V. 2020. Cryoconite: An efficient accumulator of radioactive fallout in glacial environments. The Cryosphere 14(2):657-672. https://doi.org/10.5194/tc-14-6572020

Bizzotto, E., Villa, S., Vaj, C., and Vighi, M. 2009. Comparison of glacial and non-glacial-fed streams to evaluate the loading of persistent organic pollutants through seasonal snow/ice melt. Chemosphere 74(7):924-930. https://doi. org/10.1016/j.chemosphere.2008.10.013

Bolshiyanov, D. and Makeev, V. 1995. The Severnaya Zemlya Archipelago: glaciation, history of the natural environ- 
ment. St. Petersburg: Gidrometeoizdat. 217 p. (In Russian)

Bolshiyanov, D. Y., Sokolov, V. T., Yozhikov, I. S., Bulatov, R. K., Rachkova, A. N., Fedorov, G. B., and Paramzin, A. S. 2016. Conditions of the alimentation and the variability of glaciers of the Severnaya Zemlya Archipelago from observations of 2014-2015. Ice and Snow 56(3):358-368. https://doi.org/10.15356/2076-6734-2016-3-358-368 (In Russian)

Cameron, K. A., Hodson, A. J., and Osborn, A. M. 2012. Structure and diversity of bacterial, eukaryotic and archaeal communities in glacial cryoconite holes from the Arctic and the Antarctic. FEMS Microbiology Ecology 82(2):254267. https://doi.org/10.1111/j.1574-6941.2011.01277.x

Cook,J., Edwards, A., Takeuchi, N., and Irvine-Fynn, T. 2016. Cryoconite: The dark biological secret of the cryosphere. Progress in Physical Geography-Earth and Environment 40(1):66111. https://doi.org/10.1177/0309133315616574

Cook, J., Hodson, A., Telling, J., Anesio, A., Irvine-Fynn, T., and Bellas, C. 2010. The mass-area relationship within cryoconite holes and its implications for primary production. Annals of Glaciology 51(56):106-110. https://doi. org/10.3189/172756411795932038

Di Mauro, B., Baccolo, G., Garzonio, R., Piazzalunga, A., Massabò, D., and Colombo, R. 2016. Mountain glaciers darkening: geochemical characterizazion of cryoconites and their radiative impact on the Vadret da Morteratsch (Swiss Alps). EGU General Assembly Conference Abstracts: EPSC2016-9654.

Domkin, C. 2011. Physical basics of particle size analysis by laser diffraction. Trudy Mezhdunarodnogo simpoziuma «Nadezhnost' $i$ kachestvo» 2:150-152. (In Russian)

Dumont, M., Durand, Y., Arnaud, Y., and Six, D. 2012. Variational assimilation of albedo in a snowpack model and reconstruction of the spatial mass-balance distribution of an alpine glacier. Journal of Glaciology 58(207):151164. https://doi.org/10.3189/2012JoG11J163

ESRI. "Topographic". February 19, 2012. Scale Not Given. "World Topographic Map".

Ferrario, C., Pittino, F., Tagliaferri, I., Gandolfi, I., Bestetti, G., Azzoni, R. S., Diolaiuti, G., Franzetti, A., Ambrosini, R., and Villa, S. 2017. Bacteria contribute to pesticide degradation in cryoconite holes in an Alpine glacier. Environmental Pollution 230:919-926. https://doi.org/10.1016/j. envpol.2017.07.039

Fountain, A.G., Tranter, M., Nylen, T.H., Lewis, K.J., and Mueller, D.R. 2004. Evolution of cryoconite holes and their contribution to meltwater runoff from glaciers in the McMurdo Dry Valleys, Antarctica. Journal of Glaciology 50(168):35-45. https://doi. org/10.3189/172756504781830312

Gagarina, E. I. 2004. Lithological factor of soil formation (on the example of the Northwest of the Russian Plain). St. Petersburg: St Petersburg University Press. (In Russian)

Gajda, R. 2008. Cryoconite phenomena on the Greenland Ice Cap in the Thule Area. The Canadian Geographer / Le Géographe canadien 3:35-44. https://doi. org/10.1111/j.1541-0064.1958.tb01802.x

Gee, G. W. and Or, D. 2002. 2.4 Particle-size analysis. Methods of soil analysis: Part 4 physical methods 5:255-293. https://doi.org/10.2136/sssabookser5.4.c12

Glazovskaya, M. 1952. Aeolian fine-grained deposits on the glaciers of the Terskey Ala Tau ridge. Trudy Instituta geografii ANSSSR (49):55. (In Russian)

Glazovskaya, M. 1958. Weathering and primary soil formation in Antarctica. Nauchnyye Doklady Vysshey Shkoly, GeologoGeograficheskiye nauki 1:63-76. (In Russian)
Goldberg, E. D. 1985. Black carbon in the environment: properties and distribution.

Goryachkin, S. V., Mergelov, N. S., and Targulian, V. O. 2019. Extreme Pedology: Elements of Theory and Methodological Approaches. Eurasian Soil Science (1):5-19. https:// doi.org/10.1134/s0032180×19010040 (In Russian)

GPM. 2016. GPM 1.2.1.0008.15 Determination of particle size distribution by laser light diffraction. (In Russian)

Hildes, D. H., Clarke, G. K., Flowers, G. E., and Marshall, S. J. 2004. Subglacial erosion and englacial sediment transport modelled for North American ice sheets. Quaternary Science Reviews 23(3-4):409-430. https://doi. org/10.1016/j.quascirev.2003.06.005

Hodson, A., Anesio, A. M., Tranter, M., Fountain, A., Osborn, M., Priscu, J., Laybourn-Parry, J., and Sattler, B. 2008. Glacial ecosystems. Ecological Monographs 78(1):41-67. https:// doi.org/10.1890/07-0187.1

Jahn, R., Blume, H., Asio, V., Spaargaren, O., and Schad, P. 2006. Guidelines for soil description: FAO.

Kachinsky, N. 1958. Mechanical and microaggregate composition of soil, methods of its study.

Kowalski, B. and Andrianova, G. 1970. Micronutrients in soils of the USSR/Academy of Sciences of the USSR. Scientific Council on problems of microelements in animal husbandry and crop production. (In Russian)

Kutuzov, S.S., Mikhalenko, V. N., Shahgedanova, M. V., Ginot, P., Kozachek, A. V., Kuderina, T. M., Lavrentiev, I. I., and Popov, G. V. 2014. Ways of far-distance dust transport onto Caucasian glaciers and chemical composition of snow on the Western plateau of Elbrus. Ice and Snow 54(3):5-15. https://doi.org/10.15356/2076-6734-2014-35-15 (In Russian)

Langford, H., Hodson, A., Banwart, S., and Bøggild, C. 2010. The microstructure and biogeochemistry of Arctic cryoconite granules. Annals of Glaciology 51(56):87-94. https://doi.org/10.3189/172756411795932083

Lee, K., Do Hur, S., Hou, S., Hong, S., Qin, X., Ren, J., Liu, Y., Rosman, K. J., Barbante, C., and Boutron, C. F. 2008. Atmospheric pollution for trace elements in the remote high-altitude atmosphere in central Asia as recorded in snow from Mt. Qomolangma (Everest) of the Himalayas. Science of the Total Environment 404(1):171-181. https:// doi.org/10.1016/j.scitotenv.2008.06.022

Levitan, M. A., Girin, Y. P., Luksha, V. L., Kubrakova, I. V., Roshchina, I. A., Sattler, B., Tyutyunnik, O. A., and Chudetskii, M. Y. 2011. Modern sedimentation system of Lake Untersee, East Antarctica. Geochemistry International 49(5):459-481. https://doi.org/10.1134/s0016702911050077

Li, Q., Kang, S., Wang, N., Li, Y., Li, X., Dong, Z., and Chen, P. 2017. Composition and sources of polycyclic aromatic hydrocarbons in cryoconites of the Tibetan Plateau glaciers. Science of the Total Environment 574:991-999. https://doi.org/10.1016/j.scitotenv.2016.09.159

Łokas, E., Zawierucha, K., Cwanek, A., Szufa, K., Gaca, P., Mietelski, J. W., and Tomankiewicz, E. 2018. The sources of high airborne radioactivity in cryoconite holes from the Caucasus (Georgia). Scientific Reports 8(1):1-10. https:// doi.org/10.1038/s41598-018-29076-4

MacDonell, S. and Fitzsimons, S. 2008. The formation and hydrological significance of cryoconite holes. Progress in Physical Geography-Earth and Environment 32(6):595610. https://doi.org/10.1177/0309133308101382

MacDonell, S. and Fitzsimons, S. 2008. The formation and hydrological significance of cryoconite holes. Progress in Physical Geography 32(6):595-610. https://doi. org/10.1177/0309133308101382

Manousakas, M., Popovicheva, O., Evangeliou, N., Diapouli, E., Sitnikov, N., Shonija, N., and Eleftheriadis, K. 2020. 
Aerosol carbonaceous, elemental and ionic composition variability and origin at the Siberian High Arctic, Cape Baranova. Tellus B: Chemical and Physical Meteorology 72(1):1-14. https://doi.org/10.1080/16000889.2020.180 3708

Masiello, C.A. 2004. New directions in black carbon organic geochemistry. Marine Chemistry 92(1-4):201-213. https://doi.org/10.1016/j.marchem.2004.06.043

Matsuoka, K., Skoglund, A., and Roth, G. 2018. Quantarctica. Norwegian Polar Data Centre. https://doi.org/10.21334/ npolar.2018.8516e961

Matveyeva, N. 2006. Vegetation of the southern part of Bolshevik Island (Severnaya Zemlya archipelago). Vegetation of Russia 8:3-87. https://doi.org/10.31111/vegrus/2006.08.3

McIntyre, N. F. 1984. Cryoconite hole thermodynamics. Canadian Journal of Earth Sciences 21(2):152-156. https://doi. org/10.1139/e84-016

Mueller, D. R. and Pollard, W. H. 2004. Gradient analysis of cryoconite ecosystems from two polar glaciers. Polar Biology 27(2):66-74. https://doi.org/10.1007/s00300003-0580-2

Mukhametova, N., Abakumov, E., and Rumin, A. 2013. Particle size distribution of Antarctic soils by sedimentometry and laser diffraction. Agrophysica (3):1-6. (In Russian)

Nagatsuka, N., Takeuchi, N., Uetake, J., and Shimada, R. 2014. Mineralogical composition of cryoconite on glaciers in northwest Greenland. Bulletin of Glaciological Research 32:107-114. https://doi.org/10.5331/bgr.32.107

Nagatsuka, N., Takeuchi, N., Uetake, J., Shimada, R., Onuma, Y., Tanaka, S., and Nakano, T. 2016. Variations in Sr and $\mathrm{Nd}$ isotopic ratios of mineral particles in cryoconite in Western Greenland. Frontiers in Earth Science 4:93. https://doi.org/10.3389/feart.2016.00093

Owens, P. N., Blake, W. H., and Millward, G. E. 2019. Extreme levels of fallout radionuclides and other contaminants in glacial sediment (cryoconite) and implications for downstream aquatic ecosystems. Scientific Reports 9(1):1-9. https://doi.org/10.1038/s41598-019-48873-z

Petrakov, D., Tutubalina, O., Shpuntova, A., Kovalenko, N., Usubaliev, R., Azisov, E., and Mikhailukova, P. 2019. Assessment of glacier albedo in the Ak-Shyirak Mountains (Inner Tien Shan) from ground-based and Landsat data. Earth's Cryosphere 23(3):13-24. https://doi.org/10.21782/ KZ1560-7496-2019-3(13-24)

Podgorny, I. A. and Grenfell, T. C. 1996. Absorption of solar energy in a cryoconite hole. Geophysical Research Letters 23(18):2465-2468. https://doi.org/10.1029/96GL02229

Ramanathan, V. and Carmichael, G. 2008. Global and regional climate changes due to black carbon. Nature Geoscience 1(4):221-227. https://doi.org/10.1038/ngeo156

Ruth, U., Wagenbach, D., Steffensen, J.P., and Bigler, M. 2003. Continuous record of microparticle concentration and size distribution in the central Greenland NGRIP ice core during the last glacial period. Journal of Geophysical Research: Atmospheres 108(4098). https://doi. org/10.1029/2002JD002376

Shein, E. 2005. Soil physics course. Moscow: Moscow University Press. (In Russian)

Shein, E. 2009. The particle-size distribution in soils: Problems of the methods of study, interpretation of the results, and classification. Eurasian Soil Science 42(3):284-291. https://doi.org/10.1134/S1064229309030053

Shein, E. and Madi, A. 2018. Particle size distribution of soils: methods of laser diffraction and sedimentometry, their comparison and use. Agrochemical Herald 1: 9-11. https://doi.org/10.24411/0235-2516-2018-00003 (In Russian)
Shishkov, V., Zazovskaya, E., Mergelov, N., and Dolgikh, A. 2017. Soils forming on cryoconites material in the retreat zone of the glacier. Earth's Cryosphere: Past, Present and Future: International Conference. Russia, Pushchino 5-8.06.2017.

Shishkov, V.A., Zazovskaya, E.P., Lebedeva, M.P., Mergelov, N. S., and Dolgikh, A. V. 2016. Micromorphology of soils on cryoconites in extreme environmental conditions formed in the area of Aldegond glacier retreat (Western Spitzbergen). Morfologiya pochv: ot makro- do submikrourovnya: all Russian conference. Russia, Moscow 19-21.12.2016. (In Russian)

Singh, S. M., Sharma, J., Gawas-Sakhalkar, P., Upadhyay, A. K., Naik, S., Pedneker, S. M., and Ravindra, R. 2013. Atmospheric deposition studies of heavy metals in Arctic by comparative analysis of lichens and cryoconite. Environmental Monitoring and Assessment 185(2):1367-1376. https://doi.org/10.1007/s10661-012-2638-5

Takeuchi, N. 2002. Optical characteristics of cryoconite (surface dust) on glaciers: the relationship between light absorbency and the property of organic matter contained in the cryoconite. Annals of Glaciology 34:409-414. https://doi.org/10.3189/172756402781817743

Takeuchi, N. and Li, Z. 2008. Characteristics of surface dust on Ürümqi glacier No. 1 in the Tien Shan mountains, China. Arctic, Antarctic, and Alpine Research 40(4):744$750 . \quad$ https://doi.org/10.1657/1523-0430(07-094) [TAKEUCHI]2.0.CO;2

Takeuchi, N., Kohshima, S., and Seko, K. 2001. Structure, formation, and darkening process of albedo-reducing material (cryoconite) on a Himalayan glacier: A granular algal mat growing on the glacier. Arctic, Antarctic, and Alpine Research 33(2):115-122. https://doi.org/10.2307/1552211

Targulian, V. O., Mergelov, N. S., and Goryachkin, S. V. 2017. Soil-like bodies on Mars. Eurasian Soil Science 50(2):185197. https://doi.org/10.1134/s1064229317020120

Tieber, A., Lettner, H., Bossew, P., Hubmer, A., Sattler, B., and Hofmann, W. 2009. Accumulation of anthropogenic radionuclides in cryoconites on Alpine glaciers. Journal of Environmental Radioactivity 100(7):590-598. https://doi. org/10.1016/j.jenvrad.2009.04.008

Ukalska-Jaruga, A., Smreczak, B., and Klimkowicz-Pawlas, A. 2019. Soil organic matter composition as a factor affecting the accumulation of polycyclic aromatic hydrocarbons. Journal of Soils and Sediments 19(4):1890-1900. https://doi.org/10.1007/s11368-018-2214-x

Uspenskaya, E. V., Syroeshkin, A., Pleteneva, T., and Dobrovolsky, V. 2016. Pharmacopoeial methods for determining the size of particles. The method of laser light diffraction in the control of heterogeneity of drugs. Health and Education Millennium 18(9):112-115. (In Russian)

Usyagina, I., Ilyin, G., Mescheryakov, N., and Valuyskaya, D. 2019. Sources of natural and artificial radionuclides in the Svalbard Archipelago. Ekologicheskaya, promyshlennaya i energeticheskaya bezopasnost' - 2019: all Russian Conference Russia, Sevastopol 23-26.09.2019. (In Russian)

Ward, J. H. 1963. Hierarchical grouping to optimize an objective function. Journal of the American Statistical Association 58(301):236-244. https://doi.org/10.2307/2282967

Weiland-Bräuer, N., Fischer, M.A., Schramm, K.-W., and Schmitz, R. A. 2017. Polychlorinated biphenyl (PCB)-degrading potential of microbes present in a cryoconite of Jamtalferner Glacier. Frontiers in Microbiology 8:1105. https://doi.org/10.3389/fmicb.2017.01105

Weisleitner, K., Perras, A., Moissl-Eichinger, C., Andersen, D. T., and Sattler, B. 2019. Source environments of the microbiome in perennially ice-covered Lake Unter- 
see, Antarctica. Frontiers in Microbiology 10:1019. https:// doi.org/10.3389/fmicb.2019.01019

Weisleitner, K., Perras, A. K., Unterberger, S. H., Moissl-Eichinger, C., Andersen, D. T., and Sattler, B. 2020. Cryoconite hole location in East-Antarctic Untersee Oasis shapes physical and biological diversity. Frontiers in Microbiology 11:1165. https://doi.org/10.3389/fmicb.2020.01165

Weisleitner, K., Perras, A. K., Unterberger, S. H., Moissl-Eichinger, C., Andersen, D. T., and Sattler, B. 2020. Cryoconite hole location in East-Antarctic Untersee Oasis shapes physical and biological diversity. Figshare. https://doi. org/10.3389/fmicb.2020.01165.s001

Wharton Jr, R. A., McKay, C. P., Simmons Jr, G. M., and Parker, B.C. 1985. Cryoconite holes on glaciers. Bioscience 35(8):499-503. https://doi.org/10.2307/1309818
Wientjes, I. G. M., Van De Wal, R. S. W., Reichart, G. J., Sluijs, A., and Oerlemans, J. 2011. Dust from the dark region in the western ablation zone of the Greenland ice sheet. The Cryosphere 5(3):589-601. https://doi.org/10.5194/tc-5589-2011

WRB, I. W. G. 2015. World reference base for soil resources 2014, update 2015: International soil classification system for naming soils and creating legends for soil maps: $\mathrm{FAO}$, Rome.

Zawierucha, K., Buda, J., Azzoni, R. S., Niśkiewicz, M., Franzetti, A., and Ambrosini, R. 2019. Water bears dominated cryoconite hole ecosystems: densities, habitat preferences and physiological adaptations of Tardigrada on an alpine glacier. Aquatic Ecology 53(4):543-556. https:// doi.org/10.1007/s10452-019-09707-2 